\title{
Vehnänrankkijauhon rehuarvo lihasikojen ruokinnassa
}

\author{
Maija-Liisa Salo \\ Helsingin yliopiston kotieläintieteen laitos, 00710 Helsinki 71
}

\section{Nutritive value of wheat distillers dried grains with solubles for growing pigs}

Maija-Liisa Salo

Department of Animal Husbandry, University of Helsinki, $00710 \mathrm{Helsinki} 71$.

\begin{abstract}
The digestibilities of two feeds of wheat distillers dried grains with solubles were determined with pigs, live weights $70-80 \mathrm{~kg}$. In the alchol manufacture the grains of feed No. 1 were boiled in water, the grains of feed No. 2 in the spent waste liquor of yeast, grown in the sugar beet molasses. The composition of feeds were much alike, with the exception of a higher ash content in feed No. 2.

The digestibilities of feed No. 1 were higher, the differences being significant in organic matter $(\mathrm{P}<0.05)$ and in NFE $(\mathrm{P}<0.001)$. There were no significant differences in nitrogen balances,

The energy values calculated on the basis of trials were for feeds 1 and 2 (95\% DM) 10.26 and $8.36 \mathrm{MJ}$ metabolizable energy/kg, and 1.36 and $1.61 \mathrm{~kg}$ feed/F.U. The crude protein values were 227 and $204 \mathrm{~g}$ DCP $/ \mathrm{kg}$, respectively.
\end{abstract}

\section{Johdanto}

Rankki on alkoholiteollisuuden sivutuote. Alkoholin valmistuksessa hiiva fermentoi viljan tärkkelyksen alkoholiksi, mikä tislataan pois. Jäljelle jäänyt viljajätteen ja hiivan seos kuivataan rankkirehuksi. Tärkkelyksen häviämisen vuoksi rankin raakaproteiini-, kuitu- ja rasvapitoisuus nousee raaka-aineeseen nähden 2-3-kertaiseksi. Energia-arvo on sen vuoksi viljan arvoa alempi, mutta raakaproteiinipitoisuus suurempi. Valkuaisarvo ei kuitenkaan nouse samassa suhteessa kuin valkuaispitoisuus, sillä prosessointi huonontaa valkuaisen sulavuutta ja laatua.

Märehtijöille käytettynä rankki on hyvä valkuaisrehu, koska valkuaisen liukoisuuden huononeminen on märehtijälle vain etu ja heikkoon aminohappokoostumukseen ei tarvitse kiinnittää huomiota. Sikojen ruokinnassa sen sijaan nämä molemmat seikat ovat puutteita. Lihasikojen rehuun on kuitenkin käytetty 5-10\% rankkirehua ilman että kasvutulokset ovat huonontuneet (Wahlstrom ym. 1970, Anon. 1971). Jos perusrehu on ollut monipuolista ja sisältänyt lysiiniä yli miniminormin, on rankkilisäys saanut olla $15 \%$, mutta $25 \%$ on silloinkin ollut liikaa (Livingstone ja Livingston 1969). Tiineillä emakoilla rankkijauholla on voitu korvata valkuaisrehu kokonaankin, kunhan 
rehuyhdistelmän lysiinipitoisuus on täyttänyt emakon vaatimukset (THONG ym. 1978).

Maassamme rankki on yleensä käytetty märehtijäin rehuksi joko tuoreena tai kuivattuna. Viime vuosina kuivattua rankkia on kuitenkin alettu lisätä myös sikojen rehuihin, koska valkuaisrehujen tuontia pyritään vähentämään ja sika on tuontivalkuaisen suurin kuluttaja.

Tämän tutkimuksen tarkoituksena oli sulavuus- ja tasekokeen avulla selvitellä kahden rankkirehun rehuarvoa lihasian ruokinnassa.

\section{Aineisto ja menetelmät}

\section{Rehut}

Rankkirehut olivat peräisin Alko Oy:n Rajamäen tehtaalta. Kummassakin raaka-aineena oli vehnä. Rehujen valmistus poikkesi toisistaan siinä, että rehun n:o 1 kohdalla ("rankkirehu») vilja oli sekoitettu veteen, rehun n:o 2 kohdalla (mrankkiseos») taas hiivan emäveteen. Emävesi oli hiivatehtaan jätelientä, minkä puhdistamiselta täten säästyttiin. Energialähteenä hiivan valmistuksessa oli sokerijuurikasmelassi. Jatkokäsittely alkoholin ja rankkirehun valmistuksessa oli kummassakin tapauksessa sama: keitto, fermentointi, alkoholin tislaus ja jätteen sumutuskuivaus rehuksi. Rankkirehujen vesipitoisuus oli noin $5 \%$. Ainoa oleellinen ero rehujen koostumuksessa oli rehun n:o 2 suurempi tuhkapitoisuus (taulukko 1), mikä johtui hiivan emäveden sisältämistä kivennäisistä.

Perusrehuna sulavuuskokeessa oli ohra, minkä sulavuus oli edellä määritetty (SALO 1978). Lisäksi siat saivat kivennäisseosta ja vitamiiniseosta normien mukaisesti.

\section{Koe-eläimet ja koeohjelma}

Kokeessa oli kuusi leikkoporsasta, kolme kummallakin rankkirehulla. Niiden painot olivat kokeen alkaessa keskimäärin $72 \mathrm{~kg}$ ja päättyessä $81 \mathrm{~kg}$.

Koe suoritettiin kokonaiskeruumenetelmällä ohran sulavuuskokeen jatkona. Siirto rankkidieetille tapahtui kolmen päivän aikana. Koejakson pituus oli 12 vrk, mistä 7 vrk oli totutuskautta ja 5 vrk keruukautta.

Siat saivat päivässä 2095 g ohrajauhoa, 540 g rankkijauhoa, 50 g kivennäisseosta ja 15 g vitamiiniseosta. Ruokinta tapahtui kahdesti päivässä. Kukin rehu punnittiin erikseen ja sekoitettiin keskenään. Jauhon päälle kaadettiin kaksinkertainen määrä vettä ja se sekoitettiin velliksi. Siat söivät heti kaiken rehun. Syönnin jälkeen niille tarjottiin vettä. Väliajoiksi kaukalot käännettiin nurin. Sikalan lämpötila oli $17-21^{\circ} \mathrm{C}$.

Sonta ja virtsa kerättiin aamuisin ja niistä otettiin tietty prosenttimäärä analyysinäytteeksi. Viimeisenä keruupäivänä kerättiin kaukalon edessä olevalta muovikalvolta sian syödessään roiskima rehu, mikä vähennettiin tähteenä. Virtsankeruuastiassa oli rikkihappoa pitämässä $\mathrm{pH}: \mathrm{n}$ 1-2 tienoilla.

\section{Määritykset}

Jauhojen ja sonnan kuiva-ainepitoisuus määritettiin kuivauskaapissa $103^{\circ}$ C:ssä. Analyysinäytteeksi tulevat sontaerät kuivattiin vakuumikuivaajassa $40-50^{\circ} \mathrm{C}: s s a$. Jauhot ja sonta jauhettiin $0.5 \mathrm{~mm}: \mathrm{n}$ seulaa käyttäen. 
Näytteistä tehtiin virallinen rehuanalyysi standardimenetelmiä käyttäen. Aminohappomääritykset tehtiin Valtion teknillisen tutkimuskeskuksen laboratoriossa. Rankkirehujen sulavuudet laskettiin differenssinä. Ryhmien väliset erot testattiin t-testillä.

\section{Tulokset ja tarkastelu}

Rankkirehujen koostumus oli tuhkaa lukuunottamatta varsin samanlainen (taulukko 1), mutta rehu n:o 1 suli rehua n:o 2 paremmin (taulukko 2). Ero oli merkitsevä orgaanisessa aineessa $(\mathrm{P}<0.05)$ ja typettömissä uuteaineissa $(\mathrm{P}<0.001)$. Hiivan emävesi keittoliemenä siten huononsi sulavuutta, vaikka se vähän alensikin rankkirehun kuitupitoisuutta.

Taulukko 1. Vehnänrankkirehujen kemiallinen koostumus.

Table 1. Chemical composition of wheat distillers dried grains with solubles.

\begin{tabular}{|c|c|c|}
\hline & \multicolumn{2}{|c|}{ Rehu - Feed } \\
\hline & No 1 & No 2 \\
\hline \multicolumn{3}{|l|}{$\%$ ka:sta $-\%$ of $D M$} \\
\hline Raakaproteiini - Crude profein .......... & 35.8 & 34.3 \\
\hline Raakarasva - Ether extract ............... & 6.2 & 5.0 \\
\hline Raakakuitu - Crude fibre ................. & 9.0 & 7.6 \\
\hline 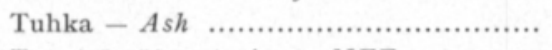 & 9.1 & 13.8 \\
\hline Typettömät uuteain. $-N F E \ldots \ldots \ldots \ldots . .$. & 39.9 & 39.3 \\
\hline \multicolumn{3}{|l|}{$g / 16 g N$} \\
\hline Lysine ....................................... & 2.3 & 2.1 \\
\hline 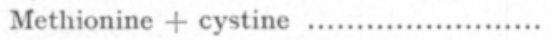 & 1.9 & 1.8 \\
\hline 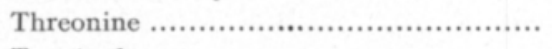 & 3.5 & 3.7 \\
\hline 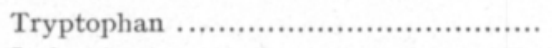 & 0.8 & 0.7 \\
\hline 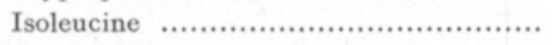 & 3.5 & 3.5 \\
\hline 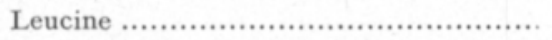 & 6.3 & 6.5 \\
\hline 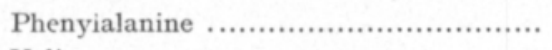 & 4.2 & 4.5 \\
\hline 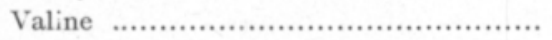 & 4.4 & 4.5 \\
\hline 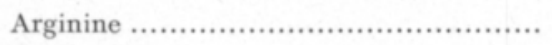 & 3.2 & 2.8 \\
\hline 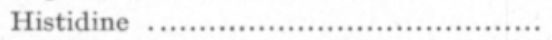 & 1.9 & 1.7 \\
\hline
\end{tabular}

Taulukko 2. Vehnänrankkirehujen sulavuudet lihasialla.

Table 2. Digestibilities of wheat distillers dried grains with solubles by growing pigs.

\begin{tabular}{llc}
\hline & \multicolumn{2}{c}{ Rehu - Feed } \\
\cline { 2 - 3 } & No 1 & No 2 \\
\hline Orgaaninen aine - Organic matter, $\% \ldots \ldots \ldots \ldots$ & $62.9 \pm 0.8^{*}$ & $54.1 \pm 3.4^{*}$ \\
Raakaprotetini - Crude protein, $\% \ldots \ldots \ldots \ldots \ldots$ & $66.7 \pm 3.2$ & $62.7 \pm 5.3$ \\
Raakarasva - Ether extract, $\% \ldots \ldots \ldots \ldots \ldots \ldots \ldots$ & $78.1 \pm 7.6$ & $71.1 \pm 10.0$ \\
Raakakuitu - Crude fibre, $\% \ldots \ldots \ldots \ldots \ldots \ldots \ldots$. & $39.3 \pm 13.7$ & $51.5 \pm 36.6$ \\
Typettömät uuteain. - NFE, $\% \ldots \ldots \ldots \ldots \ldots \ldots$. & $58.4 \pm 0.6^{* * *}$ & $45.6 \pm 1.5^{* * *}$ \\
\hline
\end{tabular}

Keskiarvojen erot t-testillä testattuna. - Differences between means tested by the t-test: $*=\mathrm{P}<0.05,{ }^{* * *}=\mathrm{P}<0.001$. 
Sioille laadittujen rehutaulukoiden rankkirehuista nyt tutkitut poikkesivat selvimmin siinä, että ne sisälsivät rehutaulukkorehuja enemmän raakaproteiinia ja tuhkaa ja vähemmän typettömiä uuteaineita. Myös uuteaineiden sulavuus oli alempi. Toisaalta myös ruotsalaisen (ERIKSSON ym. 1972) ja saksalaisen (NEHRING ym. 1970) rehutaulukon rankkirehut poikkeavat toisistaan sekä koostumukseltaan että sulavuudeltaan.

Todettujen sulavuuskertoimien perusteella laskettiin virallista laskumallia käyttäen (NJF:n rehutaulukko 1969) muuntokelpoisen ja nettoenergian arvot (taulukko 3). Laskelma osoitti, että hiivaliemen käyttö huononsi rankkirehun rehuyksikköarvoa lähes $20 \%$. Parempi rehu oli ME-arvoltaan melkein yhtä hyvää kuin ERIKsSON ym:n (1972) rehutaulukon rankkirehu (10.67 MJ ME/kg $95 \%$ ka sisältävää rehua). THONG ym. (1978) referoimien kahden sikakokeen rankkirehujen ME-arvot olivat vielä paremmat. Eräs syy eroon on raakaaineena käytetty maissi.

Taulukko 3. Vehnänrankkirehujen muuntokelpoisen ja nettoenergian sekä sulavan raakaproteinin arvot lihasialla.

Table 3. Metabolizable energy (ME), net energy (F.U.) and digestible crude protein values of wheat distillers dried grains with solubles by growing pigs.

\begin{tabular}{|c|c|c|}
\hline \multicolumn{3}{|c|}{$\begin{array}{c}\text { Rehu }(95 \% \mathrm{ka})-\text { Feed }(95 \% D M) \\
\text { No } 1\end{array}$} \\
\hline 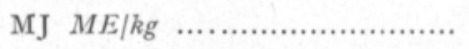 & 10.26 & 8.37 \\
\hline $\mathrm{Kg} / \mathrm{ry}-K g / F . \quad U . \ldots \ldots \ldots \ldots \ldots \ldots \ldots$ & 1.30 & 1.61 \\
\hline Srv, $\mathrm{g} / \mathrm{kg}-D C P, g / k g \ldots \ldots \ldots \ldots \ldots$ & 227 & 204 \\
\hline Srv, g/ry $-D C P, g / F . U . \ldots \ldots$ & 295 & 328 \\
\hline
\end{tabular}

F. $U .=0.7 x$ starch units.

Tutkittujen rankkirehujen raakaproteiinipitoisuudet olivat lähes samat, mutta koska hiivan emävettä keittoliemenä käytetyssä rehussa raakaproteiinin sulavuus oli alempi, oli rehukilon srv-sisältö pienempi.

Typpitaseessa ei rehujen välillä ollut merkitsevää eroa: rehulla n:o 1 se oli $9.8 \pm 0.7$ ja rehulla n:o $211.7 \pm 1.0 \mathrm{~g} \mathrm{~N}$ sikaa kohti päivässä. Typen pidättyminen oli vähäistä verrattuna edellä suoritettuun ohran sulavuuskokeeseen, missä valkuaisrehuna oli rankkijauhon sijasta rehumaitojauhe (SALO 1978).

Raakavalkuaisarvoltaan molemmat rehut poikkesivat edukseen tässä kirjoituksessa referoitujen tutkimusten ja rehutaulukoiden rankkirehuista. Raakaproteiinipitoisuuden ero oli 5-12\%-yksikköä ja johtui ilmeisesti siitä, että yleisin alkoholin valmistukseen käytetty viljalaji on maissi ja se sisältää valkuaista vähemmän kuin vehnä.

Suoritetusta tutkimuksesta ja kirjallisuustiedoista voidaan päätellä, että rankkirehujen rehuarvo sikojen ruokinnassa saattaa melko paljon vaihdella. Viljalaji on eräs vaihtelun syy, mutta ei ainoa, kuten tästäkin tutkimuksesta kävi ilmi.

Vehnänrankin nettoenergia-arvon todettiin olevan keskimäärin noin kaksi kolmasosaa ohran arvosta ja srv-pitoisuuden ohraan nähden kaksi ja puoli- 
kertaisen. Valkuaisen todellinen arvo ei kuitenkaan ole näin hyvä, koska rankin aminohappokoostumus on ohraa huonompi. Suurin heikkous rankin valkuaisessa on sen huono lysiiniarvo. Lysiini on tunnetusti herkästi tuhoutuva aminohappo ja prosessoinnin laadulla saattaa olla vaikutusta lysiinin hyväksikäyttöön, koska eri sikakokeiden tulokset ovat tässä kohden jonkin verran ristiriitaisia (Livingstone ja Livingston 1969, Wahlstrom ym. 1970, Thong ym. 1978).

Myös viljan rasvan ja kivennäisten pitoisuudet konsentroituvat rankissa parantaen osaltaan sen rehuarvoa. B-vitamiinien pitoisuudet nousevat vielä enemmän, koska käymisprosessissa muodostuu hiivaa, mikä on hyvä B-vitamiinilähde. N3. tuntemattomia kasvutekijöitäkin rankista on etsitty, mutta tulokset ovat ristiriitaisia (HARROLD 1967, ANON. 1971).

\section{Tiivistelmä}

Kahden vehnänrankkirehun sulavuus määritettiin $70-80$ kiloisilla lihasioilla. Rehun n:o 1 keittoliemenä alkoholinvalmistuksessa oli ollut vesi, rehun n:o 2 hiivan emävesi. Rehujen koostumus tuhkaa lukuunottamatta oli varsin samanlainen.

Rankkirehu n:o 1 suli rehua n:o 2 paremmin, ero oli merkitsevä orgaanisessa aineessa $(\mathrm{P}<0.05)$ ja typettömissä uuteaineissa $(\mathrm{P}<0.001)$. Typpitaseissa ei ollut merkitsevää eroa.

Koetuloksista $95 \%$ ka sisältäville rehuille 1 ja 2 lasketut rehuarvot olivat seuraavat: ME-arvo 10.26 ja $8.37 \mathrm{MJ} / \mathrm{kg}$, korvausluku 1.30 ja $1.61 \mathrm{~kg} / \mathrm{ry}$ sekä srv-arvo 227 ja $204 \mathrm{~g} / \mathrm{kg}$.

\section{KIRJALLISUUTTA}

Anon. 1969. NJF's Fodermiddeltabel. 40 p. Gịøvik.

Anov. 1971. Cooperative regional studies with growing swine: effects of unidentified factor ingredients on rate and efficiency of gain of growing swine. NCR-42 Commitee on Swine Nutrition. J. Anim. Sci. 31: 900-906.

Eriksson S. SANne S. \& Thomke S. 1972. Fodermedlen 251 p. Boràs.

Harrold R. L. 1967. Further studies of corn distillers dried solubles fractions with rats, pigs and chicks. Dissertation Abstr. (B) 28:2202 B-2203 B. Ref. Nutr. Abstr. Rev. 38: 8285 .

Livingstonk R. M. \& Livingston D. M. S. 1969. A note on the use of distillers' by-products in diets for growing pigs. Anim. Prod. 11: 259-261.

Nehring K., Becer, M. \& Hoffmann, B. 1970. Futtermitteltabellenwerk. 460 p. Berlin.

SALO, M.-L. 1978. Hehtolitrapainon ja lajikkeen vaikutus ohran rehuarvoon sikojen ruokinnassa. Maatal.tiet. Aikak. 50: 285-290.

Thong, L. A., Jensen, A. H., Harmon, B. G. \& Cornelius, S. G. 1978. Distillers dried grains with solubles as a supplemental protein source in diets for gestating swine. J. Anim. Sci. 46: $674-677$.

Wahlstrom, R. C., German, C. S. \& Libal, G. W. 1970 . Corn distillers dried grains with solubles in growing-finishing swine rations. J. Anim. Sci. 30:532-535. 